\title{
Dampak Handphone Android Terhadap Minat Belajar Siswa Kelas XI IPS Di SMAN 3 Kota Bima
}

\author{
Indri Kristiwati ${ }^{1} \operatorname{Irfan}^{2}$ dan Arifuddin ${ }^{3}$ \\ Program Studi Pendidikan Sosiologi STKIP Bima \\ Jalan Piere Tendean Kel. Mande Tlp.Fax (0374) 42801, Bima 84191, Indonesia \\ (Email; ifanfagih@gmail.com)
}

\begin{abstract}
Abstrak
Berdasarkan hasil observasi awal pada tanggal 18 April 2019 siswa kelas XI IPS di SMA Negeri 3 Kota Bima, siswa lebih cenderung menggunakan Handphonenya untuk menghabiskan waktunya untuk bermain dari pada digunakan untuk belajar. Kondisi demikian tidak dapat di biarkan berlarur-larut tanpa pemecahan masalahnya. Sementara itu, penelitian, diketahui bahwa minat belajar siswa masih di rasakan kurang dari yang di harapkan. Lemahnnya minat belajar siswa, hal ini di tunjukan kurang semangatnya siswa dalam mengikuti mata pelajaran di kelas terutama mata pelajaran sosiologi di sekolah yang di mana kurangnya minat tersebut di pengaruhi oleh penggunaan Handphone yang di mainkan oleh siswa secara terus-menerus sebagai media bermain. Apabila perilaku seperti ini tetap dipertahankan, maka akan dapat mematikan kreatifitas siswa, sehingga mengakibatkan rendahnya minat belajar siswa, dan berpengaruh pada hasil belajar yang di capai. Oleh karena itu untuk meningkatkan minat belajar siswa perlu adanya perhatian lebih dari orang tua agar anak tidak cenderung fokus untuk bermain Handphone saja tetapi harus fokus untuk belajar agar minat dan motivasi anak meningkat. Jenis penelitian yang digunakan dalam penelitian ini adalah kualitatif deskriptif yaitu studi yang bertujuan untuk mendeskripsikan atau menjelaskan peristiwa atau kejadian sebelum dan sesudah dilapangan. Data yang di peroleh kemudian di olah dan ditafsirkan dan disimpulkan. Pendekatan yang di gunakan dalam penelitian ini adalah pendekatan kualitatif. Teknik pengumpulan data yang di gunakan dalam penelitian ini adalah dengan menggunakan teknik observasi/pengamatan, wawancara dan dokumentasi. Hasil penelitian ini menunjukan bahwa ada dampak handphone android terhadap minat belajar siswa kelas XI IPS SMA Negeri 3 Kota Bima tahun pelajaran 2019/2020.
\end{abstract}

Kata Kunci : Dampak, Handphone Android, Minat Belajar Siswa.. 


\section{Pendahuluan}

Pendidikan mempunyai peranan yang sangat penting dalam membangun sebuah negara. Menurut Undang-Undang No.20 Tahun 2003 menyatakan bahwa pendidikan adalah usaha sadar dan terencana untuk mewujudkan suasana belajar dan proses pembelajaran agar peserta didik secara aktif mengembangkan potensi dirinya untuk memiliki kekuatan spiritual keagamaan, pengendalian diri, kepribadian, kecerdasan, akhlak mulia, serta keterampilan yang diperlukan dirinya, masyarakat, bangsa dan negara (Hasbullah 2005:4). Tetapi seperti yang kita ketahui perkembangan teknologi informasi sekarang ini semakin pesat, berbagai kemajuan teknologi dapat kita peroleh dengan mudahnya seiring dengan perkembangan zaman. Penggunaan telepon genggam semakin marak di kalangan masyarakat mulai dari pengusaha, ibu-ibu, mahasiswa, pelajar, sopir, tukang ojek, sampai penjual sayuran. Handphone saat ini sudah menjadi suatu kebutuhan pokok bagi masyarakat baik dari kalangan bawah,menengah,maupun atas sudah menggunakan Handphone.

Handphone Android merupakan salah satu alat komunikasi yang sangat canggih dan modern yang mempunyai fungsi yang sama dengan telepon genggam dan dapat di bawa kemana-mana tanpa di sambung dengan jaringan telepon menggunakan kabel dan memiliki berbagai banyak fungsi dan kegunaan oleh semua orang yang menggunakannya baik dalam hal yang positif maupun negatif. Pada hakikatnya, kemajuan teknologi dan pengaruhnya dalam kehidupan adalah hal yang tidak dapat kita hindari, di karenakan saat ini dapat kita lihat kemajuan teknologi yang telah mempengaruhi gaya hidup dan perilaku masyarakat, memang pengaruh kemajuan teknologi zaman dahulu dan di zaman sekarang berbeda, pada zaman dahulu teknologi belum secanggih di zaman sekarang. Yang menggunakan
Handphone Android bukan hanya di kalangan masyarakat, akan tetapi pada saat ini di dalam dunia pendidikan Handphone Android telah marak di gunakan oleh kalangan peserta didik, baik di gunakan sebagai media informasi maupun sebagai media pembelajaran. penggunaan Handphone Android bagi peserta didik menjadikan dunia teknologi semakin lama semakin canggih. Komunikasi yang dulunya memerlukan waktu yang lama dalam penyampaianya, kini dengan Handphone Android segalanya menjadi sangat cepat dan seakan tanpa jarak. Di zaman yang serba praktis dan modern sekarang ini banyak peserta didik yang menggunakan Handphone Android dalam kegiatan sehari-hari, baik peserta didik SMP maupun SMA telah di perbolehkan membawa Handphone Android di sekolah. Peserta didik dapat menggunakan teknologi Handphone Android ini secara positif maupun negatif tergantung pada setiap individu. Contoh positif dari penggunaan Handphone Android adalah memanfaatkan Handphone untuk membantu peserta didik sebagai media pembelajaran. Namun, ada beberapa hal yang perlu di khawatirkan dalam pemanfaatan Handphone Android oleh peserta didik seperti penggunaan tidak sesuai kondisi. Misalnya menggunakan Handphone dalam proses pembelajaran untuk sms-an dengan teman atau untuk bermain game, facebook whatsapp dan lain sebagainya. Oleh karena itu orang tua harus selalu mengontrol semua yang di lakukan oleh anak-anaknya di dalam Handphone tersebut agar anak-anaknya tidak menyalahgunakan fasilitas yang di berikan oleh orang tuanya. Seperti yang kita ketahui lingkungan keluarga merupakan lingkungan pendidikan yang pertama, karena dalam keluarga inilah anak pertama-tama mendapatkan didikan dan bimbingan. Juga di katakan lingkungan yang utama, karena sebagian besar dari kehidupan anak adalah di dalam 
keluarga, sehingga pendidikan yang paling banyak di terima oleh anak adalah dalam keluarga. Tugas utama dari keluarga bagi pendidikan anak ialah sebagai peletak dasar bagi pendidikan akhlak dan pandangan hidup keagamaan. Sifat dan tabiat anak sebagian besar di ambil dari kedua orang tuanya dan dari anggota keluarga yang lain (Hasbullah,2005:38).

Fenomena yang dijelaskan di atas juga terdapat di SMA Negeri 3 Kota Bima, yang di mana SMA Negeri 3 Kota Bima ini hampir semua siswa dan siswinya memiliki Handphone Android untuk memenuhi kebutuhan mereka baik di sekolah maupun di luar sekolah, yang dimana Handphone tersebut mereka gunakan dengan hal yang positif dan negatif tergantung dari siswa yang menggunakannya. Hal yang positif yang di maksud adalah terdapat beberapa siswa yang menggunakan Handphone Android tersebut dengan mencari materi pelajaran, mengerjakan tugas yang diberikan oleh guru-guru, membuat makalah dan lain sebagainya. Sedangkan sebagian siswa ada yang menggunakannya dengan hal-hal yang negatif sehingga dapat membuat peserta didik malas belajar, mengganggu konsentrasi belajar siswa, melupakan tugas dan kewajiban, mengganggu perkembangan anak dan lain-lain. Sehingga pada saat kegiatan belajar mengajar berlangsung terdapat beberapa siswa saja yang aktif di dalam ruangan karena banyak yang tidak fokus pada pembelajaran. Materi yang dijelaskan oleh guru dan metode yang digunakan di depan ruangan sudah bagus akan tetapi timbal balik dari siswa masih kurang sehingga banyak masalah yang ditemukan peneliti di dalam ruangan seperti terdapat beberapa siswa yang suka keluar masuk di ruangan, tidak mau mencatat materi yang disampaikan, tidak mau mengerjakan pekerjaan rumah, mengganggu teman satu ruangan, sering suka terlambat dan lain sebagainya, dampak yang terjadi di akibatkan karena siswa fokus terhadap sosial media. Ini menjadi sebuah masalah yang harus diatasi sehingga berefek pada siswa itu sendiri seperti sikap dan tingkah laku tidak sama dengan siswa-siswa lain yang tidak menyalah gunakan Handphone. Dan pada saat ulangan harian terdapat beberapa siswa saja yang mendapatkan nilai di atas KKM dan bahkan ada juga yang menyontek punya teman sebangkunya karena mereka tidak belajar terlebih dahulu. Mereka gunakan Handphone Android sebagai media belajar pada saat ada tugas dari guru saja apabila tidak ada tugas mereka tidak gunakan untuk mencari materi tetapi mereka gunakan untuk bermain sosial media.

Dengan adanya masalah yang ditemukan di tempat penelitian, peneliti ingin mengetahu lebih dalam lagi bagaimana dampak penggunaan Handphone terhadap minat belajar siswa. Hasil pra-observasi bahwa penggunaan Handphone Android terhadap siswa kurang efesien, siswa lebih mengutamakan untuk bermain sosial media seperti facebook, whatsapp dan lain-lain dibandingkan untuk mencari materi pelajaran dan di dalam ruangan tersebut dari jumlah siswa sebanyak 23 orang hanya 3 orang saja yang tidak menggunakan Handphone Android. Oleh karena itu, peneliti sangat tertarik mengangkat tema "Dampak Handphone Android Terhadap Minat Belajar Siswa Kelas XI Di SMA Negeri 3 Kota Bima".

\section{Tinjauan Pustaka}

\section{Handphone Android}

Syerif Nurhakim

(2015:41)

Handphone (HP) adalah perangkat telekomunikasi elektronik yang mempunyai kemampuan dasar yang sama dengan telepon konvensional saluran tetap, namun dapat di bawa ke mana-mana dan tidak perlu di sambung dengan jaringan telepon menggunakan kabel. Telepon 
genggam atau Handphone merupakan alat komunikasi dua arah yang memungkinkan dua orang atau lebih untuk bercakap-cakap tanpa terbatas jarak. Berdasarkan pengertian di atas dapat di simpulkan bahwa Handphone merupakan alat komunikasi multifungsi yang berukuran kecil dan praktis sehingga dapat di bawa kemana-mana. Handphone tersebut merupakan perkembangan teknologi telepon yang dari masa ke masa mengalami perubahan di mana perangkat Handphone tersebut dapat di gunakan sebagai sarana komunikasi baik itu berupa lisan maupun tulisan untuk penyampaian informasi atau pesan dari suatu pihak kepihak lainnya secara efektif dan efisien karena perangkatnya yang bisa di bawa kemana-mana dan dapat di pakai di mana saja. Adapun beberapa pengertian Handphone Android menurut para ahli adalah sebagai berikut:
a. Menurut Teguh Arifianto (2011:1), Handphone Android merupakan perangkat bergerak pada sistem operasi untuk telepon seluler yang berbasis linux.

b. Menurut Hermawan (2011:1), Handphone Android merupakan OS (operating system) mobiel yang tumbuh di tengah OS lainya yang berkembang dewasa ini. OS lainya seperti windows Mobile, iphone OS, symbian, dan masih banyak lagi. Akan tetapi, OS yang ada ini berjalan dengan memprioritaskan aplikasi inti yang di bangun sendiri tanpa melihat potensi yang cukup besar dari aplikasi pihak ketiga. Oleh karena itu, adanya keterbatasan dari aplikasi pihak ketiga untuk mendapatkan data asli ponsel, berkomunikasi antar proses serta keterbatasan distribusi aplikasi pihak ketiga untuk platform mereka.

Berdasarkan pendapat di atas, maka di tarik kesimpulan bahwa Android adalah sistem operasi berbasis linux yang sedang berkembang di tengah OS lainya.

\section{Fungsi Handphone Android}

Sebelumnya sudah di jelaskan bahwa pada dasarnya Handphone memiliki fungsi untuk membuat dan menerima panggilan, Handphone juga memiliki fungsi pengiriman dan penerimaan pesan singkat atau short message service. Seiring dengan perkembangan dunia teknologi digital maka Handphone juga mengalami pelebaran fungsi. Kini Handphone di lengkapi dengan berbagai fitur canggih, seperti pemutar audio (mp3) dan video, kamera digital, bluetooth, game dan layanan interner (layanan GPRS, 3G). Selain itu, Handphone sekarang telah dilengkapi dengan sistem operasi seperti Android, Ios, Blackberry, dan Windows Mobile. Sistem operasi tersebut membuat Handphone memiliki fungsi yang sama dengan komputer. Dengan Handphone anda juga dapat menjelajahi dunia internet untuk mengakses informasi di seluruh penjuru dunia. Bahkan kini kebanyakan masyarakat menyebutnya dengan ponsel pintar (smartPhone) karena dapat membantu pekerjaan manusia. Adapun beberapa fungsi Handphone Menurut (Dewa Langit:2017) adalah sebagai berikut:

1) Sebagai Alat Komunikasi Agar Tetap Terhubung Dengan Teman Atau Keluarga $65 \%$

2) Sebagai Simbol Kelas Masyarakat $44 \%$

3) Sebagai Penunjang Bisnis $45 \%$

4) Sebagai Alat Penghilang Stres 36 $\%$ 


\section{Dampak Handphone Android}

Adapun dampak positif dan negatif dalam penggunaan Handphone adalah sebagai berikut:

\section{1) Dampak Positif}

Adapun Yang Menjadi Dampak Positif Dalam Penggunaan Handphone Menurut Beatus Mendelson Laka (2012:3).

a) Sebagai media komunikasi, ponsel dapat di gunakan untuk menghubungi keluarga, kerabat, atau teman yang berjarak jauh dari kita. Dengan begitu, kita tidak perlu bersusah payah mengirim surat yang akan membutuhkan waktu yang lama untuk sampai ke tujuannya.

b) Sebagai media informasi, dengan adanya internet, Handphone akan bisa mengakses berbagai hal yang dapat memberikan kita informasi penting atau berharga. Informasi tersebut juga dapat meningkatkan pengetahuan kita.

c) Sebagai media pembelajaran, sekarang tugas-tugas yang di berikan kepada peserta didik sangatlah banyak, khususnya pada jenjang SMP dan SMA. Handphone dapat membantu peserta didik mengerjakan tugastugas tersebut dengan bantuan internet yang sudah tersedia di Handphone. Jadi, siswa dengan mudah dapat belajar melalui internet dengan memanfaatkan Handphone tersebut.

d) Sebagai media hiburan, di dalam Handphone terdapat berbagai aplikasi yang bersifat menghibur. Saat kita sedang bosan, kita dapat memainkan aplikasi tersebut seperti halnya mendengar $\mathrm{mp} 3$, bermain game dan lain sebagainya.

e) Dunia kerja dan bisnis, Handphone juga dapat di gunakan untuk menjalin atau melakukan hubungan kerja dan bisnis. Handphone dapat di gunakan sebagai media hubung antar klien. Selain itu kita juga dapat melakukan proses jual beli Online melalui Handphone.

\section{2) Dampak Negatif}

Adapun Beberapa Dampak Negatif Dari Handphone Menurut (Uswatun,2017) Yaitu:

a) Membuat Peserta Didik Malas Belajar

Anak-Anak yang sudah kecanduan Handphone, maka setiap saatnya banyak bermain Handphone saja mereka tidak lagi berfikir pada hal yang lain. Bagi mereka Handphone merupakan teman setia yang setiap saat ke mana-mana selalu di bawa, rasanya tidak lengkap tanpa Handphone di genggamannya. Pada saat belajar di rumah siswa mendampingi buku dengan Handphone pada awalnya mendengarkan musik atau Mp3 untuk menciptakan suasana belajar yang nyaman akan tetapi ketika bunyi telepon atau SMS (Short Messege Service) maka buku itu di tinggalkan siswa berpaling ke Handphone. Mereka malas belajar dan lebih senang telepon (Talking) dan SMS. Keberadaan Handphone memang sangat penting bagi kehidupan di jaman era globalisasi seperti sekarang ini. Tetapi jika ternyata Handphone di salahgunakan maka akan berdampak negatif. Seperti, Handphone yang semestinya belum diberikan kepada siswa tetapi sudah diberikan kalau memang jika siswa bisa memanfaatkan sesuai fungsinya maka itu sangat baik tetapi tidak sedikit siswa yang 
menyalahgunakan Handphone dari fungsinya dan pada akhirnya Handphone tersebut dapat mengganggu proses belajar dan menurunkan prestasi belajar siswa.

b) Mengganggu Konsentrasi Belajar Siswa

Konsentrasi adalah tingkat perhatian kita terhadap sesuatu, dalam konteks belajar berarti tingkat perhatian siswa terpusat terhadap segala penjelasan atau bimbingan yang di berikan guru. Seharusnya ketika seorang guru sedang memberikan materi pelajaran seluruh perhatian siswa harus terfokus kepada penjelasan guru tersebut. Akan tetapi sering sekali Handphone yang mereka punya menjadi salah satu penyebab konsentrasi siswa menurun, bagaimana tidak ketika seorang guru sedang menjelaskan pelajaran siswa lebih asyik memainkan Handphone seperti SMSan dengan temannya, main game, bahkan update status di jejaring sosial Facebook dan lain sebagainya. Akibat dari itu semua saat evaluasi atau ulangan siswa tidak bisa menjawab soal akhirnya mendapat nilai yang buruk, dan hal itulah yang menyebabkan proses belajar gagal.

c) Melupakan Tugas Dan Kewajiban Handphone sebenarnya sangatlah bermanfaat jika dipergunakan sebagaimana mestinya. Tetapi yang terjadi khususnya para pelajar menyalahgunakan Handphone tersebut untuk keperluan lain. Anak-anak terlalu asyik bermain Handphone dengan Feature Handphone yang semakin canggih selain untuk menelpon dan SMS, Handphone tersebut sudah ada Feature permainan (Game), Mp3, Video, Kamera, Radio, Televisi, bahkan jaringan Internet. Tidak sedikit siswa melupakan tugas dan kewajibannya akibat bermain Handphone. Mereka tidak lagi memperhatikan tugas dan kewajibannya sebab disibukkan oleh Handphone yang mereka punya. Akibatnya siswa tidak menguasai materi belajarannya dan tidak sedikit siswa yang lupa mengerjakan tugas dari guru karena sibuk memainkan Handphone.

d) Mengganggu Perkembangan Anak

Dengan perkembangan alat komunikasi Handphone maka tercipta Feature canggih yang tersedia di Handphone seperti yang telah disebutkan sebelumnya akan mengganggu siswa dalam menerima pelajaran di sekolah, tidak jarang mereka disibukkan dengan menerima panggilan, SMS, misscall dari teman mereka bahkan dari keluarga mereka sendiri, lebih parah lagi ada yang menggunakan Handphone untuk mencontek (curang) dalam ulangan, bermain game saat guru menjelaskan pelajaran.

\section{Minat Belajar}

Kata minat secara etimologi berasal dari bahasa inggris "interest" yang berarti kesukaan, perhatian (kecenderungan hati pada sesuatu), keinginan jadi dalam proses belajar siswa harus mempunyai minat atau kesukaan untuk mengikuti kegiatan belajar yang berlangsung, karena dengan adanya minat akan mendorong siswa untuk menunjukan perhatian, aktivitasnya dan partisipasinya dalam mengikuti belajar yang berlangsung. 
Slameto (2010:24) minat belajar dapat di tingkatkan melalui latihan konsentrasi. Konsentrasi merupakan aktivitas jiwa untuk memperhatikan suatu objek secara mendalam. Dapat di katakan bahwa konsentrasi itu muncul jika seseorang menaruh minat pada suatu objek, demikian pula sebaliknya merupakan kondisi psikologis yang sangat di butuhkan dalam proses belajar mengajar di sekolah. Kondisi tersebut amat penting sehingga konsentrasi yang baik akan melahirkan sikap pemusatan perhatian yang tinggi terhadap objek yang sedang di pelajari. Minat belajar membentuk sikap akademik tertentu yang bersifat sangat pribadi pada setiap siswa. Oleh karena itu minat belajar harus di tumbuhkan sendiri oleh masing-masing siswa. Pihak lainya hanya memperkuat dan menumbuhkan minat atau untuk memelihara minat yang telah di miliki seseorang. Kondisi belajar mengajar yang efektif adalah adanya minat dan perhatian siswa dalam belajar. minat merupakan suatu sifat yang relatif menetap pada diri seseorang. Minat ini besar sekali pengaruhnya terhadap belajar, sebab dengan minat seseorang akan melakukan sesuatu tanpa minat seseorang tidak mungkin melakukan sesuatu.

Berdasarkan pengertian di atas maka dapat di simpulkan bahwa minat belajar adalah kecenderungan yang mengarahkan siswa terhadap bidangbidang yang ia sukai dan tekuni tanpa adanya keterpaksaan dari siapapun untuk meningkatkan kualitasnya dalam hal pengetahuan, keterampilan, nilai, sikap, minat, apresiasi, logika berpikir, komunikasi dan kreativitas. Adapun Beberapa Pengertian Minat Menurut Para Ahli Adalah Sebagai Berikut:

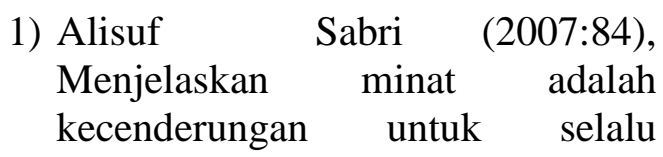
memperhatikan dan mengingat sesuatu secara terus menerus, minat ini erat kaitanya dengan perasaan, terutama perasaan senang karena itu dapat di katakan minat itu terjadi karena sikap senang kepada sesuatu. Orang yang berminat kepada sesuatu berarti sikapnya senang kepada sesuatu itu.

2) Muhibbin Syah (2001:136), Menerangkan bahwa minat adalah kecenderungan dan kegairahan yang tinggi atau keinginan yang besar terhadap sesuatu.

3) Abdul Rahman Shaleh Dan Muhbid Abdul Wahab (2004:263), Mengatakan bahwa minat juga di artikan sebagai suatu kecenderungan untuk memberikan perhatian dan bertindak terhadap orang. Aktivitas dan situasi yang menjadi objek dari minat tersebut dengan di sertai perasaan senang. Dalam batasan tersebut terkandung suatu pengertian bahwa di dalam minat ada pemusatan perhatian subjek, ada usaha untuk mendekati, mengetahui, memiliki, menguasai dan berhubungan dari subjek yang di lakukan dengan perasaan senang, ada daya penarikan dari objek.

4) Slameto (2010:180), Menjelaskan bahwa minat adalah suatu rasa lebih suka dan rasa ketertarikan pada suatu hal atau aktivitas, tanpa ada yang menyuruh. Minat pada dasarnya adalah penerimaan akan suatu hubungan antara diri sendiri dengan sesuatu di luar diri.

5) Ahmad Susanto (2013:58), Menyatakan bahwa minat merupakan dorongan dari dalam diri seseorang atau faktor yang menimbulkan ketertarikan atau perhatian secara efektif, yang 


$\begin{array}{lrr}\text { menyebabkan } & \text { dipilihnya } & \text { suatu } \\ \text { obyek atau } & \text { kegiatan } & \text { yang } \\ \text { menguntungkan, } & \text { menyenangkan } \\ \text { dan lama kelamaan akan } & \text { akan } \\ \text { mendatangkan } & \text { kepuasan dalam } \\ \text { dirinya. } & & \end{array}$

\section{Metode Penelitian}

Penelitian ini menggunakan pendekatan kualitatif, dengan desain penelitian kualitatif adalah penelitian yang menekankan pada quality atau hal yang terpenting dari sifat suatu barang atau jasa berupa kejadian atau fenomena gejala social adalah makna dibalik kejadian tersebut yang dapat di jadikan pelajaran berharga bagi suatu pengembangan konsep teori. Jenis penelitian adalah studi kasus yang merupakan jenis penelitian kualitatif yang di lakukan secara mendalam terhadap individu atau kelompok dan sebagainya dalam waktu yang di tentukan. Data yang digunakan adalah data primer dan data sekunder. Informan sebanyak 9 orang yang ditentukan secara purposive sampling. Teknik pengumpulan data adalah observasi, wawancara dan dokumentasi. Adapun Teknik Analisis Data Dalam Penelitian Ini Adalah Reduksi Data, Display Data dan Verifikasi Data lalu pengujian keabsahan data.

\section{Hasil Penelitian}

Dampak Handphone Android terhadap minat belajar siswa antara lain: dampak positif dan negatif yang di mana dampak positif yang di maksud adalah dapat mempermudah untuk berkomunikasi dengan orang-orang yang berjarak jauh ataupun dekat dengan kita sedangkan dampak negatif yang di maksud adalah dapat mempengaruhi minat belajar siswa karena siswa lebih terfokus untuk bermain dengan menggunakan handphonennya di bandingkan untuk belajar yang di mana belajar merupakan suatu aktivitas mental atau psikis yang berlangsung dalam interaksi aktif dalam lingkungan yang menghasilkan perubahan-perubahan dalam pengetahuan pemahaman, ketrampilan dan nilai sikap. Perubahan itu bersifat secara relatif konstan. Winkel dalam (Yatim Riyanto, 2009:5).

Handphone lebih banyak siswa gunakan sebagi media bermain saja dan mereka gunakan sebagai media belajar hanya sesekali saja karena mereka lebih fokus terhadap bermain dan akibat dari keasyikan bermain setiap malam mereka selalu begadang karena lupa waktu akan tidur karena keasyikan melihat informasi atau kejadian-kejadian yang ada di handphone mereka seperti postingan orang-orang yang ada di luar sana dan melakukan chatingan dengan teman atau pacar mereka sehingga kesehatan mereka di belakangi. Dan pada saat ulangan harian atau ulangan semester hanya beberapa siswa saja yang jujur sebagiannya ada yang nyontek punya teman, ada yang menjari jawaban di google dan lain sebagainya itu semua di pengaruhi oleh sosial media sehingga mereka malas untuk belajar.

Dampak Handphone Android yang pertama yang peneliti temukan di tempat penelitian yaitu dampak positifnya, yang di mana dampak positif yang pertama yaitu Handphone dapat mempermudah siswa untuk berkomuniksi dengan keluarga atau teman yang berjarak jauh dengannya dengan cara menelepon secara manual atau menelepon secara tatap muka. Fungsi Handphone sebagai alat komunikasi ini mengarah pada dampak positif Handphone sebagai media komunikasi.

Dampak Handphone Android yang kedua yaitu apabila tidak masuk sekolah siswa menggunakan Handphone tersebut untuk mencari informasi terhadap teman satu ruangannya untuk menannyakan tugas yang di berikan oleh gurunya di sekolah jadi dampak yang kedua ini mengarah pada siswa untuk mempermudah siswa dalam menanyakan iformasi pada 
temannya mengenai tugas yang di berikan oleh gurunya.

Dampak positif Handphone yang ketiga yaitu dapat mempermudah siswa untuk mencari materi atau mengerjakan tugas yang di berikan oleh gurunya dan apabila mereka tidak paham dengan tugas mereka maka dengan mudah mereka menggunakan Handphone untuk mencari materi atau mengerjakan pekerjaan rumah mereka tersebut.

Dampak positif Handphone yang ke empat yaitu apabila siswa merasakan bosan di rumah atau di manapun mereka berada mereka dapat dengan mudah membuka atau bermain dengan menggunakan Handphone mereka untuk menghilangkan kejenuhan mereka dengan cara bermain internet seperti facebook, whatsup dan lain-lain.

Faktor internal merupakan faktor yang dapat memyebabkan kesulitan belajar bagi siswa antara lain, kemampuan intelektual, perasan dan kepercayaan diri, motivasi, kematangan untuk belajar, kemampuan mengingat dan lain sebagainya. Faktor eksternal merupakan faktor yang ada di luar diri individu yaitu faktor lingkungan dan faktor keluarga dan lain-lain.

\section{Kesimpulan}

- Dampak Handphone Android yang pertama yaitu dampak positifnya, Handphone dapat mempermudah siswa untuk berkomuniksi dengan keluarga atau teman yang berjarak jauh dengannya dengan cara menelepon secara manual atau menelepon secara tatap muka. Fungsi Handphone sebagai alat komunikasi ini mengarah pada dampak positif Handphone sebagai media komunikasi.

- Dampak Handphone Android yang kedua yaitu apabila tidak masuk sekolah siswa menggunakan Handphone tersebut untuk mencari informasi terhadap teman satu ruangannya untuk menannyakan tugas yang di berikan oleh gurunya di sekolah jadi dampak yang kedua ini mengarah pada siswa untuk mempermudah siswa dalam menanyakan iformasi pada temannya mengenai tugas yang di berikan oleh gurunya.

- Dampak positif Handphone yang ketiga yaitu dapat mempermudah siswa untuk mencari materi atau mengerjakan tugas yang di berikan oleh gurunya dan apabila mereka tidak paham dengan tugas mereka maka dengan mudah mereka menggunakan Handphone untuk mencari materi atau mengerjakan pekerjaan rumah mereka tersebut.

- Dampak positif Handphone yang ke empat yaitu apabila siswa merasakan bosan di rumah atau di manapun mereka berada mereka dapat dengan mudah membuka atau bermain dengan menggunakan Handphone mereka untuk menghilangkan kejenuhan mereka dengan cara bermain internet seperti facebook, whatsup dan lainlain.

\section{Daftar Pustaka}

Bungin, Burhan, 2010. Metode Penelitian Kuantitatif: Komunikasi Ekonomi Dan Kebijakan Publik Serta IlmuIlmu Sosial Lainya. Jakarta: Kencana Prenada Media Grup

Dewantara, Ki Hadjar, 2015. Jurnal Studi Islam, Vol. 16, No 2 Desember 2015 Djamarah, 2011. Psikologi Belajar. Jakarta: Rineka Cipta

Hurlock, 2013. Psikologi Perkembangan Suatu Pendekatan Sepanjang Rentang Kehidupan, Jakarta: Erlangga

Fathurrahman, Puput, 2009. Strategi Belajar Mengajar. Bandung: PT Refika Aditama

Gunawan, Imam, 2013. Metode Penelitian Kualitatif Teori Dan Praktik. Jakarta: PT Bumi Aksara 
Hadi, 2009. Biologi Insekta Entomologi. Yogyakarta: Graha Ilmu

Hasbullah, 2005. Dasar-Dasar Ilmu Pendidikan. Jakarta: PT Rajawali Pers

Hurlock, 2000. Psikologi Perkembangan. Jakarta: Erlangga

Irham, Muhammad, 2013. Psikologi Pendidikan, Teori Dan Aplikasi Dalam Proses Pembelajaran. Jogjakarta: PT Ar-Ruzz Media

Khodijah, 2014. Psikologi Pendidikan, Jakarta:Rajawali Pers

Laka, Mendelson Beatus, 2012. Dampak Penggunaan Handphone Terhadap Perilaku Belajar Peserta Didik. Vol.7/no.2/2012 (Akses 25 april 2019, jam 18.00).

Langit, Dewa, 2017. Fungsi Handphone Bagi Masyarakat Indonesia http://repository.uinjkt.ac.id/dspace/ bitstream/123456789/1794/1/103037 -AHMAD\%20FADILAH-FITK.pdf (Akses, 5 Mei 2019)

Mahmud, 2010. Psikologi Pendidikan. Bandung: PT Pustaka Setia

Nurhakim, Syerif, 2015.Dunia Komunikasi Dan Gadget. Jakarta: PT Bestari

Rachman Abd, dkk, 2003. Psykologi Pendidikan. Yogyakarta: PT Tiara Wacana

Riyanto, 2009. Aplikasi Metodologi Penelitian Kesehatan. Yogyakarta: Nuha Medika

Sabri, Alisuf, 2007. Psikologi Pendidikan. Jakatra: PT Pedoman Ilmu Jaya

Satori, Djam'an,dkk, 2011. Metode Penelitian Kualitatif. Bandung: PT Alfabeta

Shaleh Rahman Abdul, 2004. Psikologi Suatu Pengantar. Jakarta: PT Prenada Media

Slameto, 2010. Belajar Dan Faktor Yang Mempengaruhinya. Bandung: Rineka Cipta

Slameto, 2003. Belajar Dan Faktor-Faktor Yang Mempengaruhinya. Jakarta: Rineka Cipta
Sugiyono, 2012. Metode Penelitian Kuantitatif-Kualitatif Dan $R \& \&$. Bandung: Alfabeta

Sugiyono, 2010. Metode Penelitian Administratif. Bandung: Alfabeta

Sugiyono, 2013. Metode Penelitian Kuantitatif, Kualitatif Dan $R \& D$. Bandung: PT Alfabeta

Susanto, Ahmad, 2013. Teori Belajar Dan Pembelajaran Di Sekolah Dasar. Jakarta: PT Kencana

Syah, Muhibbin, 2001. Psikologi Pendidikan Dengan Pendekatan Baru. Bandung: PT Remaja Rosdakarya

Tirtarahardja, Umar, dkk, 2008. Pengantar Pendidikan. Jakarta: PT Asdi Mahasatya

Uswatun, 2017. Dampak Positif Dan Negatif HP Bagi Pelajar, di akses dalam

http://repo.iaintulungagung.ac.id/833 4/5/BAB\%20II.pdf. (Akses, April 2019)

Usman, Ahmad, 2008. Mari Belajar Meneliti-Cetakan I, Yogyakarta: Genta Press

Walgito, 2010. Pengantar Psikolog umum, Yogyakarta: C.V Andi Offset https://galleryteknologi.wordpress.co m/2017/05/19/pengertian-androidmenurut-para-ahli/ (Akses, 11 april 2019) 